Nosan Nataliia, PhD (History), Associate Professor, Associate Professor of the Department of Economics and Entrepreneurship, Cherkasy State Technological University, Cherkassy, Ukraine

ORCID ID: 0000-0002-4005-8333

e-mail: natali_nosan@ukr.net

\title{
Retrospective Analysis of the Main Indicators of Ukraine's Financial Security
}

Abstract. Introduction. Despite the existence of an officially recommended methodology for assessing the level of economic security of the state, which contains a separate set of indicators for diagnosing the state of its financial compone nt, the last comprehensive analysis of the level of financial security of Ukraine with wide publicity of the results was conducted in 2014. The lack of official data on the state of financial security of Ukraine since 2014 necessitates an expert evaluation of its level in order to formulate in the long term a set of management and regulatory measures aimed at maintaining or stabilizing its current state.

Purpose. The purpose of the study is to establish trends that are characteristic of changing the values of the main indicators of the level of financial security in Ukraine based on a retrospective analysis of the state of a number of financial macroeconomic indicators.

Results. The materials of the research made assumptions about the possibility of conducting an express assessment of the level of financial security of the state on the basis of several basic financial indicators of the state of the national economy. The author's approach to defining the level of financial security of the state is proposed. A retrospective analysis of the dynamics of such indicators of the level of financial security of the state as a change in the money supply and monetary base, changes in the volume of deposits in national and foreign currencies, changes in lending volumes, changes in the volume of gross domestic product and in financial and insurance activities, the volume of income and expenditure of the state the budget, the size of the public debt was made.

Conclusions. The level of financial security of Ukraine, determined on the basis of separate financial indicators of the state of the national economy, proves the fact of stabilization of the state of the domestic financial system in the last two years. In general, the level of financial security of Ukraine at the beginning of 2019 can be estimated as satisfactory, howe ver, a stable financial dependence on external sources of financial resources in the near future can lead to a loss of state financial sovereignty.

Keywords: security; financial security; financial security indicators; bank security; monetary security.

\section{удК 336.71}

Носань Н. С., кандидат історичних наук, доцент, доцент кафедри економіки та підприємництва, Черкаський державний технологічний університет, м. Черкаси, Україна

\section{Ретроспективний аналіз основних індикаторів стану фінансової безпеки України}

Анотація. У матеріалах дослідження зроблено припущення щодо можливості проведення експресоцінювання стану фінансової безпеки держави на основі кількох основних фінансових індикаторів стану національної економіки. Запропоновано авторський підхід до дефініції рівня фінансової безпеки держави, згідно з яким це поняття визначено як стан захищеності національних фінансових інтересів, які реалізуються у різних секторах фінансової системи на мікро-, мезо- та макрорівнях засобами державного управління та державної фінансової політики. Проведено ретроспективний аналіз динаміки таких індикаторів рівня фінансової безпеки держави, як зміна грошової маси та монетарної бази, зміна обсягів депозитів у національній та іноземній валюті, зміна обсягів кредитування, зміна обсягу валового внутрішнього продукту та надходжень від фінансової та страхової діяльності, обсяги доходів і витрат державного бюджету, розмір державного боргу. Встановлено, що збільшення монетарної бази меншими у порівнянні з грошовою масою темпами, сигналізує про ефективність функціонування банківської системи та розширення сфери безготівкового грошового обігу, що $\epsilon$ свідченням зрілості економіки та позитивною характеристикою стану фінансової безпеки. Визначено, що для фінансової безпеки держави переважання валютного кредитування над рівнем кредитної активності в національній валюті може мати значні негативні наслідки у першу чергу через реалізацію соціальних ризиків. Виявлено, що питома вага надходжень від фінансової та страхової діяльності у структурі ВВП України є незначною, що свідчить про низький рівень розвитку вітчизняного фінансового сектору, його не готовність конкурувати з іноземними компаніями за споживача фінансових продуктів і послуг в умовах поширення тенденцій до глобалізації фінансових відносин. Зроблено припущення, що нездатність у національному масштабі компенсувати за допомогою фінансових надходжень фінансові зобов'язання свідчить про необхідність пошуку джерел до покриття дефіциту, а отже, є сигналом втрати державою фінансового суверенітету, що негативно характеризує стан фінансової безпеки країни.

Ключові слова: безпека; фінансова безпека; індикатори фінансової безпеки; банківська безпека; грошовокредитна безпека.

Стаття надійшла до редакції: 03.04.2019

Received: 03 April 2019 
Problem statement. Despite the existence of an officially recommended methodology for assessing the level of economic security of the state, which contains a separate set of indicators for diagnosing the state of its financial component, the last comprehensive analysis of the level of financial security of Ukraine with wide publicity of the results was conducted in 2014. Currently, the use of the proposed methodological approaches is complicated by the lack of information needed for the calculation of the proposed indicators, in addition, some indicators have lost their relevance. Thus, there is a need to modernize the methods of assessing the level of financial security of the state on the one hand, and on the other ? while this process continues in the methodological plane ? at the application level it is necessary to form a list of key macroeconomic and financial indicators, the values of which in the dynamics can be followed by a change in trends of a number of characteristics of the state of financial macro-security. In addition, the lack of official data on the state of financial security of Ukraine since 2014 necessitates an expert evaluation of its level in order to formulate in the long term a set of management and regulatory measures aimed at maintaining or stabilizing its current state.

Analysis of the recent research and publications. Problematic aspects of ensuring financial security and determining its current level are considered in numerous scientific publications of foreign and domestic scientists. So, Athanasoulis S., Shiller R., Van Wincoop E. investigate the issue of financial security in the context of macro markets functioning [1], a team of researchers in security science Zachosova N., Herasymenko O., Shevchenko A., Babina N., Zanora V. determine the characteristic features of financial and economic security management at the micro and macro levels [2, 3], Semjonova $N$. is studying financial security problems in the Baltic countries [4]. Different aspects of diagnosing the level of economic macro security and its financial component are studied by Hacker J. S., Huber G. A., Nichols A., Rehm P., Schlesinger M., Valletta R., Craig S. [5], Khalatur S., Pavlova G., Zhylenko K. [6], Vladychyn U., Skomorovych I., Lobozynska S. [7], Józef A. H., Bukhtiarova A., Chorna S., lastremska O., Bolgar T. [8], Derevyanko B., Nikolenko L., Syrmamiik I., Mykytenko Y., Gasparevich I. [9], Perciun R., Stratan A., Timush A. [10]. However, the dynamism of changes in the state of financial security, the constant volatility of the conditions of the functioning of the domestic financial system and the need for government authorities to obtain relevant data on the level of financial protection of national interests stimulate the conduct of new research in the chosen scientific plane.
Formulation of the research aim. The purpose of the study is to establish trends that are characteristic of changing the values of the main indicators of the level of financial security in Ukraine based on a retrospective analysis of the state of a number of financial macroeconomic indicators. To achieve the goal in the research process, the following tasks were set and solved: to specify the essence of the concept of the level of financial security of the state, to propose a list of the main financial indicators of macroeconomic statistics, the analysis of which will allow to carry out an express assessment of the level of financial security of Ukraine, to determine the trends of changing the indicators of the state of the financial component of the economic security of the national economy.

Presentation of the main research material. Under the level of financial security of the state, in the context of this study, it is proposed to understand the state of protection of national financial interests that are implemented in various sectors of the financial system at the micro, meso and macro levels by means of public administration and public finance policy.

The level of financial security of the state can be assessed by analyzing the state of individual indicators of various components of its system of provision. We will conduct a retrospective review of the values of several important indicators of Ukraine's financial security.

The level of the monetary component of financial security is characterized by indicators of money supply and monetary base, which serves the financial system of the state. The dynamics of the change of the indicated indicators in a ten-year retrospective is shown in Fig. 1.

An increase in the volume of money supply in circulation proves the sustainable development of the national economy. At the same time, such a trend may be a cause for intensification of inflationary fluctuations, price growth, etc. The increase of the monetary base is lower, compared to the money supply rate, indicating the efficiency of the banking system and the expansion of the non-cash money circulation, which indicates the maturity of the economy and is a positive characteristic of the financial security state.

An essential characteristic of the level of financial security of the state is the volume of deposits of individuals and legal entities in accounts with banks. This indicator shows the level of confidence of consumers of financial products and services to professional participants in financial services markets. At the same time, foreign currency deposits signal a reluctance to use national currency as an asset for long-term financial resources. 


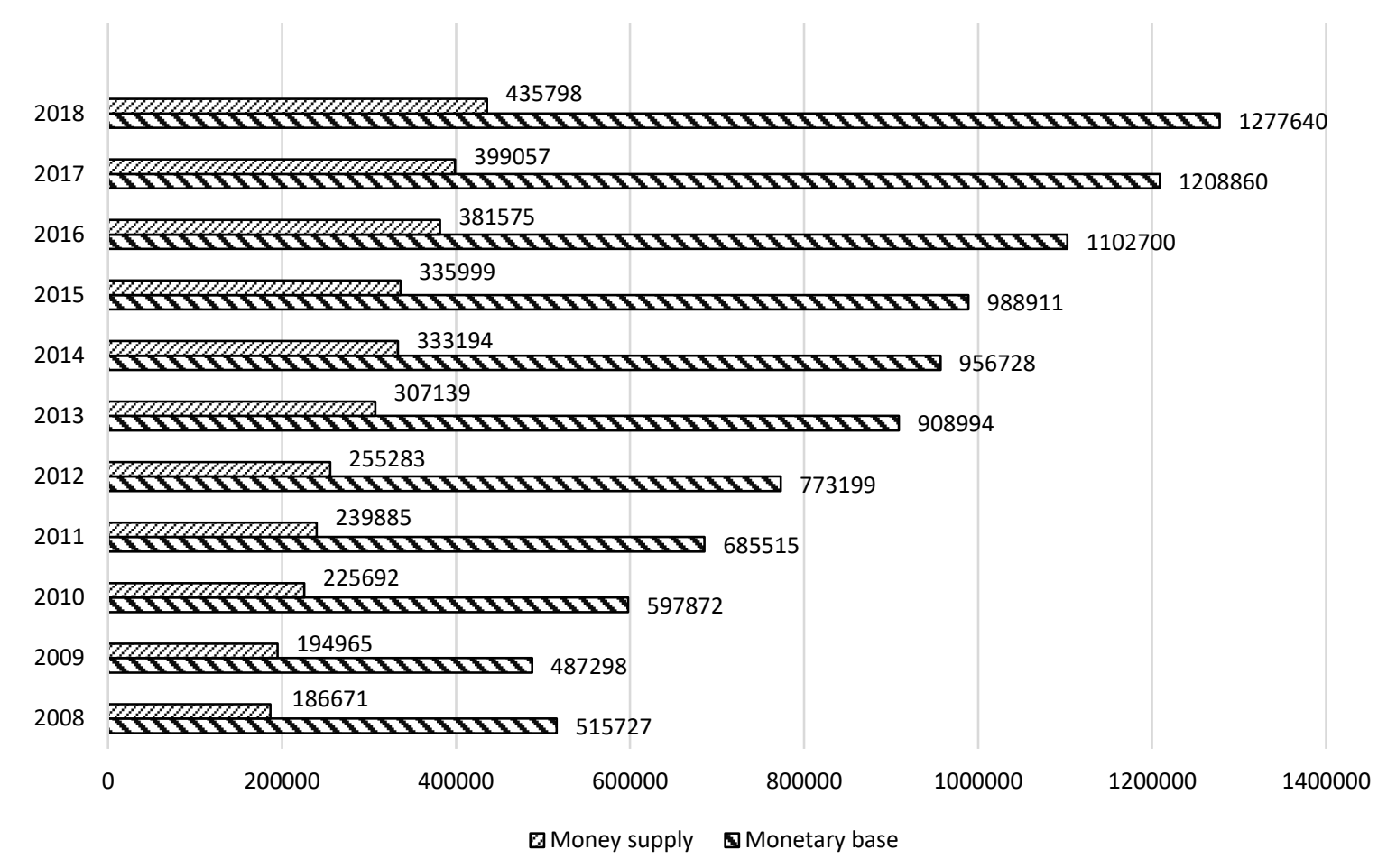

Figure 1 - Dynamics of change of money supply and monetary base, UAH million (2008-2018, as of December)

Source: compiled by author using [11]

Fig. 2 provides information on the dynamics of changes in the volume of deposits in national and foreign currency in the banking system of Ukraine. After a sharp fall in 2014, we can observe a gradual recovery of interest in the use of financial services by deposit from individuals and legal entities. Deposits in foreign currency, even in the crisis year 2014, continued to grow. As you can see, the propensity of citizens and business structures to form financial savings and financial reserves in foreign currency is noticeable for the domestic economy. The volumes of deposits in hryvnia and foreign currencies, mainly in dollars and euros, remain stable at almost the same level, indicating a high dependence of the national economy on currency fluctuations. This observation is a confirmation of the need to take measures at the state level to strengthen the currency security situation, especially now that the national regulator of the banking sector has formally abandoned the policy of strict control over the definition of the exchange rate.

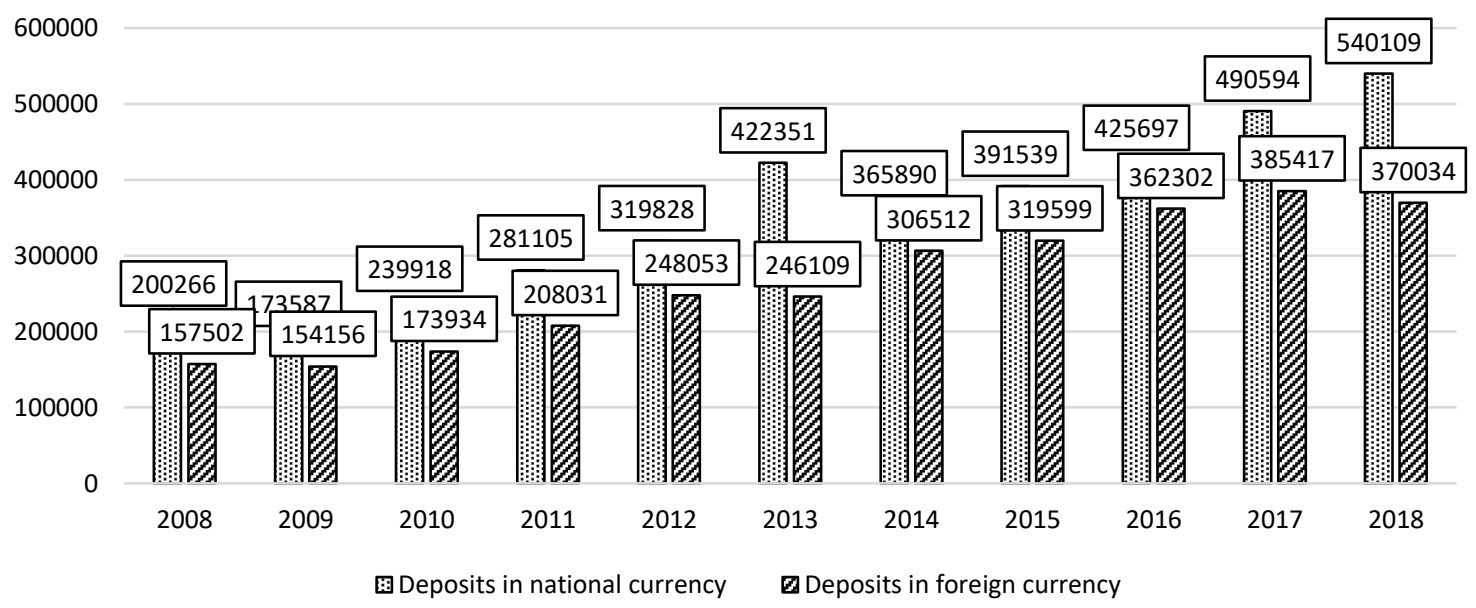

Figure 2 - Dynamics of changes in deposits volumes, UAH million (2008-2018, as of December)

Source: compiled by author using [11] 
The development of the national economy is accompanied by an increase in lending. The dynamics of lending changes, which we also consider as one of the important characteristics of the functional state, and hence the security of the banking financial sector, shows figure 3. Only two periods were recorded when foreign currency lending prevailed over loans in UAH - in 2008 and in 2015. The rapid increase in foreign currency lending in 2008 has had fatal consequences for many borrowers after the growth of the dollar exchange rate in 2009, the amount of repayment of loans and interest on them for many individuals became catastrophic to their level of well-being and personal financial security. A large number of legal entities for this reason declared themselves bankrupt; for individuals, the bankruptcy institute was launched in Ukraine only in 2018. Thus, for the financial security of the state, the predominance of foreign currency lending over the level of lending activity in the national currency can have significant negative consequences, first of all, through the realization of social risks. You can positively assess the state of Ukraine's credit security in 2018, which became a record for the national financial system by the indicator of foreign currency lending in the 10-year time analytical interval.

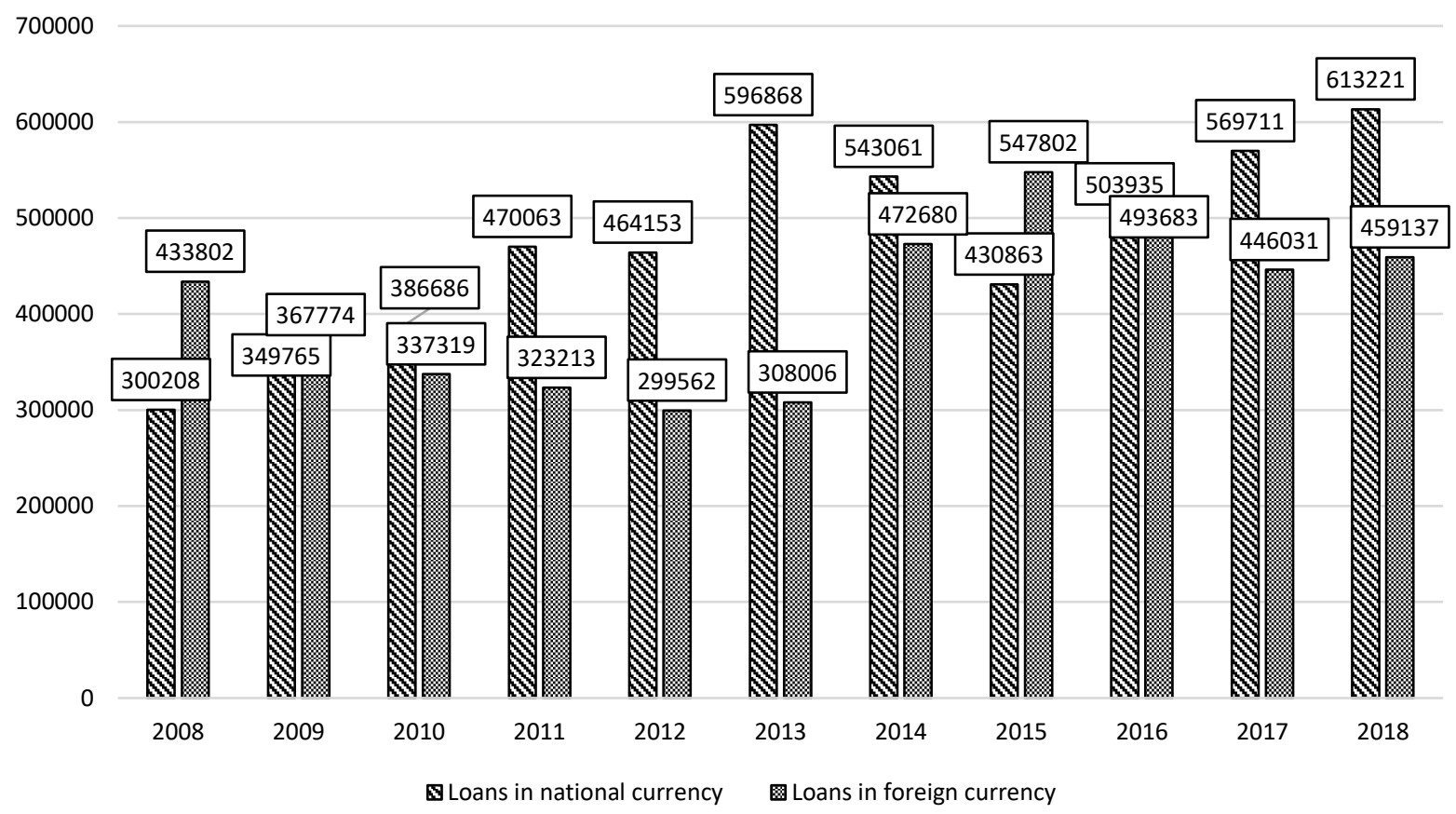

Figure 3 - Dynamics of changes in volumes of loans, UAH million (2008-2018, as of December)

Source: compiled by author using [11]

An important indicator of the level of financial security of the state is the indicator of the dynamics of changes in the gross domestic product (GDP), as well as the rate of its growth or fall. In order to characterize the state of development of the domestic financial segment, we compared the dynamics of GDP and revenues from financial and insurance activities in order to better understand the proportion of gross domestic product bringing the country's financial activities to its economic agents, and therefore, what potential has the system of national financial security for its own current functioning and development in the future (Fig. 4).

Consequently, the share of revenues from financial and insurance activities in the structure of Ukraine's GDP is insignificant. This testifies to the low level of development of the domestic financial sector, its unwillingness to compete with foreign companies for consumers of financial products and services in the context of the spread of trends towards the globalization of financial relations and European integration of Ukraine. 


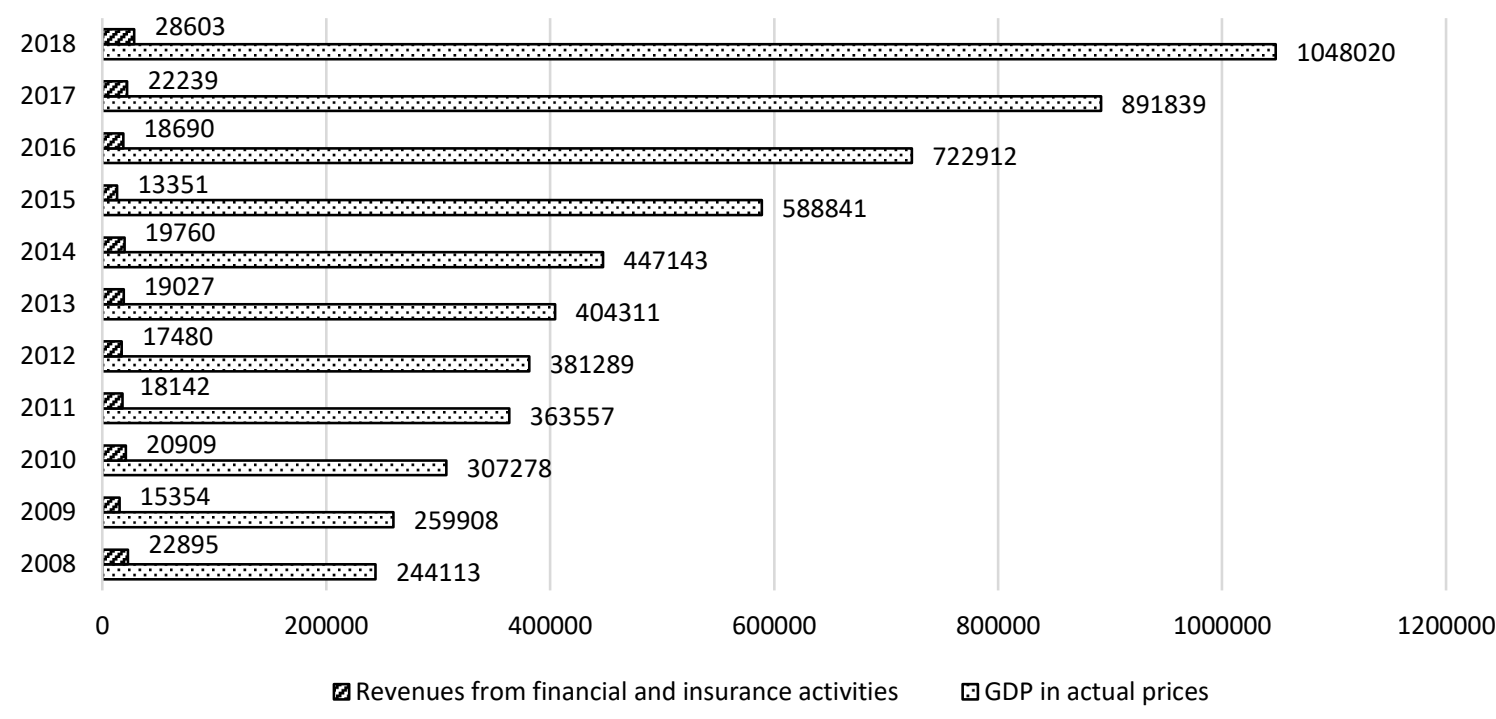

Figure 4 - Dynamics of changes in GDP and revenues from financial and insurance activities, UAH million (2008-2018, as of Q4)

Source: compiled by author using [11]

The state of two components of the country's financial characterized by the dynamics of revenues and security - debt security and budgetary security - is expenditures of the state budget (Fig. 5).

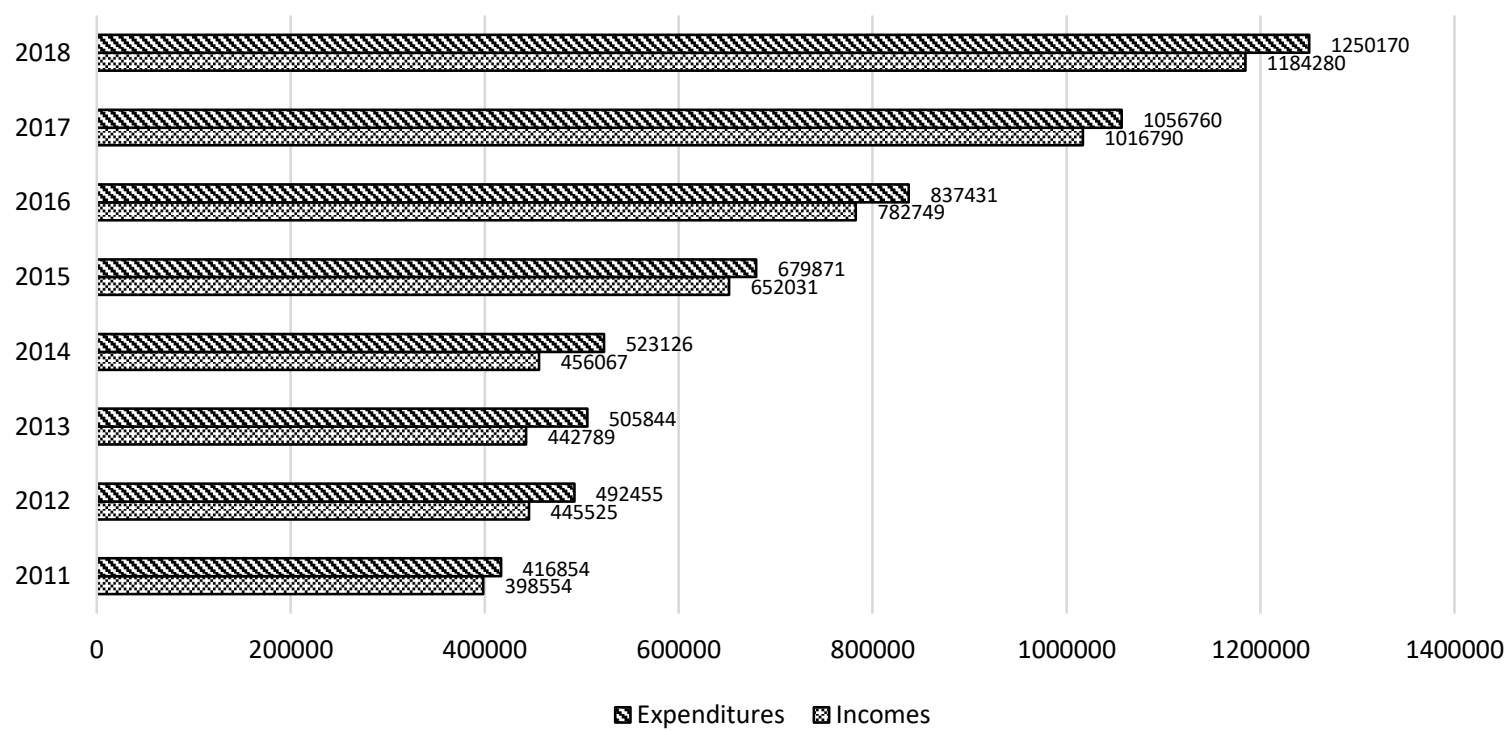

Figure 5 - The dynamics of incomes and expenditures of the state budget, UAH billion (2011-2018, as of December)

Source: compiled by author using [11]

The analysis of the dynamics of incomes and expenditures of the state budget of Ukraine shows the existence of a steady trend towards the existence of a budget deficit in the country. Its volume was minimum in 2011. Failure at a national level to compensate financial returns through financial commitments reflects the need to find sources to cover the deficit, and therefore a signal of the loss of state financial sovereignty, which negatively characterizes the financial security of the country. The gradual and stable growth of budget revenues should be positively evaluated. Thus, we can conclude that there are resources available to stabilize the budgetary security of Ukraine. At the same time, debt security remains under the influence of threats connected with an increase in the volume of expenditure of the state budget. This assumption is supported by statistics from Fig. 6 . 


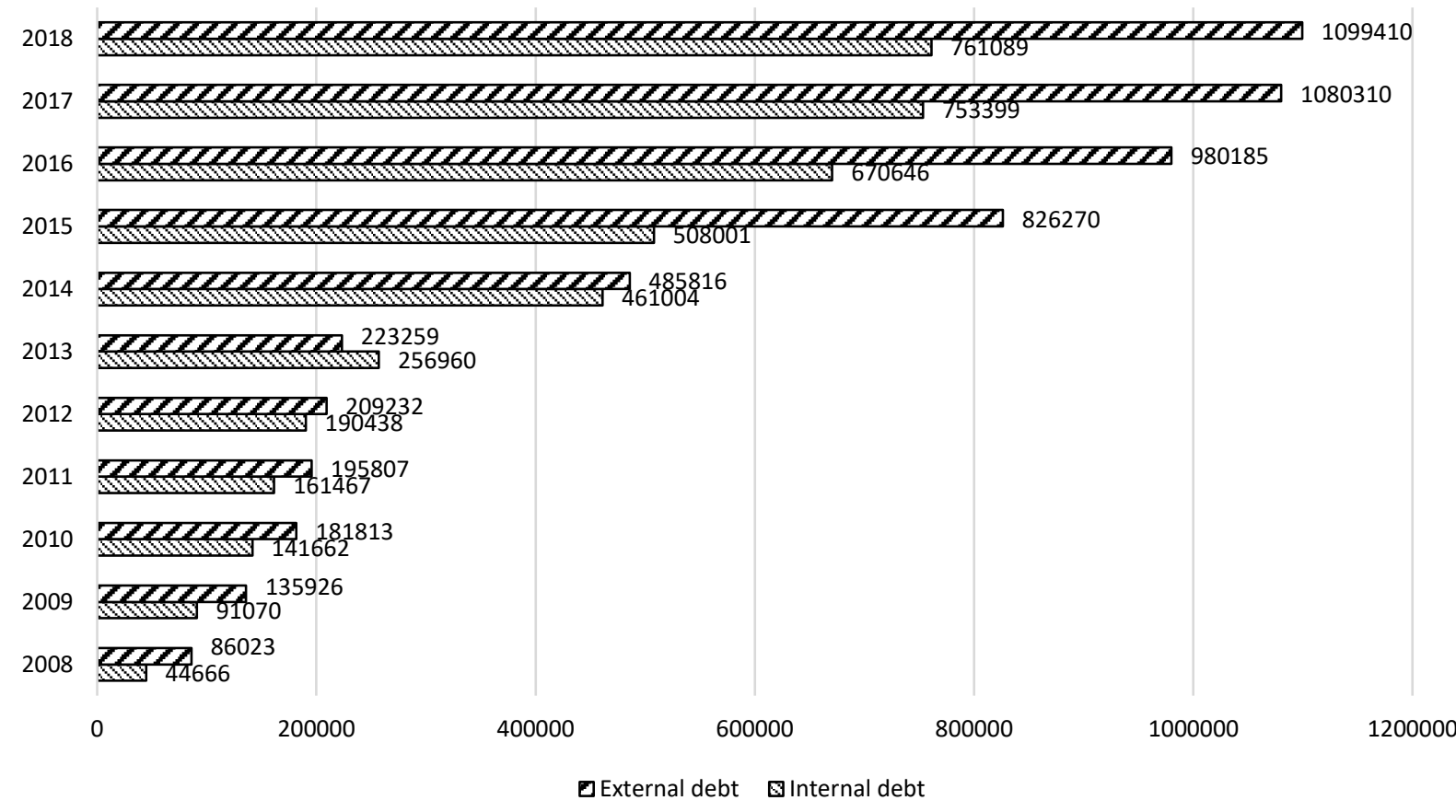

Figure 6 - The dynamics of the state debt, UAH million (2008-2018, as of December)

Source: compiled by author using [11]

If during 2008-2014 the volumes of external and internal government debt were comparable, indicating the existence of domestic sources of public finance, then during the last four years there was a tendency to seek external sources of borrowing capital. This puts our state in a condition of stable and long-term dependence on foreign donors and lenders, which in turn will be able to influence Ukraine's state financial policy on the international scene in the long run. At the national level, it is necessary to take all possible measures to enhance the financial activity of domestic investors in order to increase the level of financial security and maintain the state of financial sovereignty of the state.

Conclusions. The level of financial security of Ukraine, determined on the basis of separate financial indicators of the state of the national economy, proves the fact of stabilization of the state of the domestic financial system in the last two years. There is a revival of interest of individuals and legal entities in the use of traditional types of financial services, such as deposits in domestic and foreign currency and money lending. The negative impact on the overall assessment of Ukraine's financial security is influenced by the availability of the state budget deficit, the dependence of the financial system on foreign capital in several areas, and a small figures of the share of revenues from financial and insurance activities in the gross domestic product, indicating a low level of financial inclusion in banking and non-bank financial sector. The level of monetary security can be assessed positively, but at the state level, it is necessary to take measures to reduce the amount of cash in circulation and to carry out a large-scale explanatory work on expediency of using the possibilities of cashless payments by the population. In general, the level of financial security of Ukraine at the beginning of 2019 can be estimated as satisfactory, however, a stable financial dependence on external sources of financial resources in the near future can lead to a loss of state financial sovereignty.

Prospects for further research in the chosen field of science are the development of an updated (compared with 2013) version of the methodology for assessing the state of the country's economic and financial security, taking into account the need to quickly obtain relevant information on the existing threats to the implementation of national financial interests in the short-term and strategic prospects.

\section{Література:}

1. Athanasoulis S., Shiller R., Van Wincoop E. Macro Markets and Financial Security. FRBNY Economic policy review, 1999, p. 21-39.

2. Zachosova N., Herasymenko O., Shevchenko A. Risks and possibilities of the effect of financial inclusion on managing the financial security at the macro level. Investment Management and Financial Innovations. 2018. 15(4), p. 304-319. DOI:10.21511/imfi.15(4).2018.25.

3. Zachosova N., Babina N., Zanora V. Research and methodological framework for managing the economic security of financial intermediaries in Ukraine. Banks and Bank Systems. 2018. 13(4), p. 119-130. DOI:10.21511/bbs.13(4).2018.11. 
4. Semjonova N. Financial Security in the Baltic States: Comparison with Selected EU Countries. Economics and Business. 2016. 29, p. 90-95.

5. Hacker J. S., Huber G. A., Nichols A., Rehm P., Schlesinger M., Valletta R., Craig S. The Economic Security Index: a new measure for research and policy analysis. Special Issue: Economic Insecurity: Challenges, Issues and Findings. 2014. 60/S1, p. 5-32. DOI:10.1111/roiw.12053.

6. Khalatur S., Pavlova G., Zhylenko K. The role of some indicators of financial security in Ukraine in the context of transnationalization and national interests. Investment Management and Financial Innovations. 2018. 15(3), p. $237-248$. DOI:10.21511/imfi.15(3).2018.20.

7. Vladychyn U., Skomorovych I., Lobozynska S. Assessment of financial and economic security of Ukraine in conditions of foreign banking development. Banks and Bank Systems. 2018. 13(3), p.151-173. DOI: 10.21511/bbs.13(3).2018.15.

8. Józef A. H., Bukhtiarova A., Chorna S., lastremska O., Bolgar T. Forecasting the level of financial security of the country (on the example of Ukraine). Investment Management and Financial Innovations. 2018. 15(3), p. 304-317. DOI: 10.21511/imfi.15(3).2018.25.

9. Derevyanko B., Nikolenko L., Syrmamiik I., Mykytenko Y., Gasparevich I. Assessment of financial and economic security of the region (based on the relevant statistics of the Donetsk region). Investment Management and Financial Innovations. 2018. 15(4), p. 283-295. DOI:10.21511/imfi.15(4).2018.23.

10. Perciun R., Stratan A., Timush A. The Methodology of Financial Stability Assessment of Republic of Moldova through Macroeconomic Indicators. Procedia Economics and Finance. 2014. 15, p. 383-392.

11. Незалежна асоціація банків України URL: https://nabu.ua/ru/indikatori-groshovo-kreditnogo-rinku-2.html.

\section{References:}

1. Athanasoulis, S., Shiller, R., Van Wincoop, E. (1999). Macro Markets and Financial Security. FRBNY Economic policy review, 21-39.

2. Zachosova, N., Herasymenko, O. \& Shevchenko, A. (2018). Risks and possibilities of the effect of financial inclusion on managing the financial security at the macro level. Investment Management and Financial Innovations, 15(4), $304-319$. doi:10.21511/imfi.15(4).2018.25.

3. Zachosova, N., Babina, N., Zanora, V. (2018) Research and methodological framework for managing the economic security of financial intermediaries in Ukraine. Banks and Bank Systems,13(4), 119-130. doi:10.21511/bbs.13(4).2018.11.

4. Semjonova, N. (2016). Financial Security in the Baltic States: Comparison with Selected EU Countries. Economics and Business, 29, 90-95.

5. Hacker, J. S., Huber, G. A., Nichols, A., Rehm ,P., Schlesinger, M., Valletta, R., Craig, S. (2014). The Economic Security Index: a new measure for research and policy analysis. Special Issue: Economic Insecurity: Challenges, Issues and Findings, 60/S1, 5-32. doi:10.1111/roiw.12053.

6. Khalatur, S., Pavlova, G. \& Zhylenko, K. (2018). The role of some indicators of financial security in Ukraine in the context of transnationalization and national interests. Investment Management and Financial Innovations, 15(3), 237-248. doi:10.21511/imfi.15(3).2018.20.

7. Vladychyn, U., Skomorovych, I., Lobozynska, S. (2018). Assessment of financial and economic security of Ukraine in conditions of foreign banking development. Banks and Bank Systems, 13(3), 151-173. doi: 10.21511/bbs.13(3).2018.15.

8. Józef, A. H., Bukhtiarova, A., Chorna, S., lastremska, O. \& Bolgar, T. (2018). Forecasting the level of financial security of the country (on the example of Ukraine). Investment Management and Financial Innovations, 15(3), $304-317$. doi:10.21511/imfi.15(3).2018.25.

9. Derevyanko, B., Nikolenko, L., Syrmamiik, I., Mykytenko, Y. \& Gasparevich I. (2018). Assessment of financial and economic security of the region (based on the relevant statistics of the Donetsk region). Investment Management and Financial Innovations, 15(4), 283-295. doi:10.21511/imfi.15(4).2018.23.

10. Perciun, R., Stratan, A., Timush, A. (2014). The Methodology of Financial Stability Assessment of Republic of Moldova through Macroeconomic Indicators. Procedia Economics and Finance, 15, 383-392.

11. Independent Association of Ukrainian Banks (2018). On National Security of Ukraine. Retrieved from: https://nabu.ua/ru/indikatori-groshovo-kreditnogo-rinku-2.html [in Ukrainian]. 